\title{
Radiation damage in diopside and calcite crystals from uranothorianite inclusions.
}

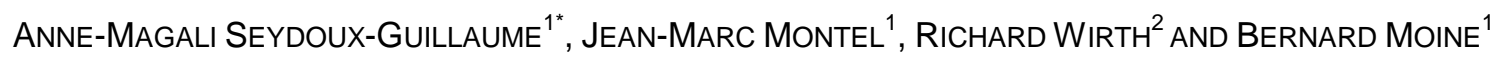

${ }^{1}$ LMTG, Université de Toulouse - CNRS - IRD, OMP, 14 avenue Edouard Belin, 31400 Toulouse, France

${ }^{2}$ GeoForschungsZentrum (GFZ) Potsdam-Division 4, Telegrafenberg, D-14473 Potsdam, Germany

*Corresponding author, Email: seydoux@Imtg.obs-mip.fr, Tel: +33 561332597

\begin{abstract}
Combining observation and simulation, radiohalos formed around urano-thorianite (UTh) from the Tranomaro granulitic skarns (SE-Madagascar) were studied. These structures consist of UTh grains surrounded by both aluminous diopside $(\mathrm{Cpx})$ and calcite $\left(\mathrm{Cc}_{1}\right)$ crystals. Optical microscope and Scanning Electron Microscope (SEM) images revealed (1) the presence of radiating cracks around the UTh probably due to swelling of the metamict UTh, (2) a diffuse optical halo at the $\mathrm{Cc}_{1} / \mathrm{UTh}$ interface, and (3) a wide "reaction zone" at the Cpx/UTh interface, composed of "secondary calcite" $\left(\mathrm{Cc}_{2}\right)$ with low temperature sheet silicate from the smectite $(\varphi)$ group. Samples prepared across various interfaces using Focused Ion Beam (FIB) were investigated by Transmission Electron Microscope (TEM). In contrast to SEM observations, there is no direct contact between $\mathrm{Cc}_{1}$ and UTh. From $\mathrm{Cc}_{1}$ to UTh, we found: (1) a large ( 200-300 nm) amorphous zone (A), enriched in $\mathrm{U}$, Th and Ca, but without $\mathrm{Si}$; (2) a chain (B) of very small ( $20 \mathrm{~nm}) \mathrm{ThO}_{2}$ crystals; (3) another amorphous zone (C), which, in contrast to zone $\mathrm{A}$ is enriched in $\mathrm{Si}$; and (4) another zone (D) made of small amorphous Si-rich "bubbles". The organization is similar for the UTh- $\mathrm{Cc}_{2}$ interface. The presence of hydrous minerals (smectite) and carbonate (calcite) in reaction zone and in cracks, the presence of $\mathrm{Pb}$-rich inclusions in secondary calcite, the abundance of fluid inclusions in the porous layer in calcite, the dissociation of $\mathrm{U}$ and $\mathrm{Th}$ in the calcite-uranothorianite layer, and the $\mathrm{ThO}_{2}$ chains along interfaces, are strong indications that low-temperature crystallization was promoted by a fluid phase. SRIM simulation was used to calculate the effect of $\alpha$ and recoil particles of the three decay chains, in Cpx, Cc and UTh. The thickness of the damaged area calculated for $\alpha$ in $\mathrm{Cpx}$ and Cc are similar to the widths of the recrystallized areas observed in thin section $(\sim 30 \mu \mathrm{m})$. Corrected with the "wandering recoil effect", the size of the damaged area calculated for recoil nuclei in Cc $(\sim 50-60 \mathrm{~nm})$ is $\sim$ multiplied by 3 and is in rather good agreement with the thickness of the totally amorphous layer at the Cc-UTh interface $(\sim 200 \mathrm{~nm})$. Finally, it is emphasized that radiohalos are a point of chemical and physical weakness in a rock and probably a starting point for alteration.
\end{abstract}

\section{Keywords: pleochroic halo; radiation damage; uranothorianite; calcite; diopside; FIB/TEM; alteration}

\section{Introduction}

During geological time, $\mathrm{U}$ - and Th-rich minerals accumulate radiation damage, mainly from $\alpha$-decay. Such damage destroys to a variable extent the host crystal network, leading to an amorphous structure, called metamict state (summary in Ewing, 1994). Damage is caused by three types of particles. First, $\alpha$-particles, which are energetic (4-8 MeV), penetrative, (10-20 $\mu \mathrm{m}$ ), but not very destructive (about 100 displacement/particle); second, recoil nuclei (daughter nuclei), which are less energetic (100-400 keV), less penetrative (20-50 nm), but more destructive (800-2000 displacement/particle); finally, fission nuclei, which are very energetic (150-200 MeV), very 
destructive (fission tracks are 10-20 $\mu \mathrm{m}$ long and 5-10 nm diameter, and made of several ten thousands displacements), but very rare $\left(0.0005 \%\right.$ of ${ }^{238} \mathrm{U}$ decays $)$. Submitted to natural radiation damages, i.e. accumulated over a long time, minerals react differently: many minerals, like zircon (review in Ewing et al., 2003) or allanite (Headley et al., 1981; Janeczek and Eby, 1993), become amorphous (metamict), whereas some remain crystalline such as monazite (Meldrum et al., 1998; Seydoux-Guillaume et al., 2002; 2004; Reviews in Ewing et al., 2003, and Ewing and Wang, 2002) or apatite (Lindberg and Ingram, 1964; Review in Ewing and Wang, 2002)

Radiation damage in radioactive minerals hase been studied in the geosciences for two main reasons. First, U-Th-rich minerals are used for U-Th- $\mathrm{Pb}$ dating, and it is essential to understand the effects of radiation damages on lead retentivity (Davis and Krogh, 2000; Lumpkin et al., 1986a; Romer, 2003). Second, the effect of long term accumulation of radiation damage is a key parameter for assessing the durability of ceramics that could be used as nuclear-waste forms (Ewing, 1975; Ewing et al., 1988; Ewing et al., 1995; Weber et al., 1998).

Four strategies are used to study radioactive damage in minerals (see review in Ewing et al., 2000): (1) external irradiation by ion beams (e.g. Meldrum et al., 1998; Wang and Ewing, 1992); (2) atomistic simulations (e.g. Crocombette and Ghaleb, 2001; Trachenko et al., 2001); (3) synthesis of doped-crystal with short-lived isotopes (e.g. Begg et al., 2000; Burakov et al., 2002); (4) study of old naturally radioactive minerals in various geological contexts by using various analytical methods like IR (Zhang and Salje, 2001), EXAFS (Farges and Calas, 1991; Harfouche et al., 2005), Raman (Nasdala et al., 1995), RMN (Farnan et al., 2003), RPE (Balan et al., 2005), and TEM (Black et al., 1984, Lumpkin et al., 1986a; Murakami et al., 1991; Weber et al., 1994). The most studied minerals are those that are either used for $\mathrm{U}-\mathrm{Th}-\mathrm{Pb}$ geochronology or expected to be good candidate for nuclear waste storage, and many papers have been published on zircon (review in Ewing et al., 2003), monazite (review in Ewing et al., 2002; Seydoux-Guillaume et al., 2004), titanite (Vance and Metson, 1985; Hawtorne et al., 1991; Lumpkin et al., 1991; Farges, 1997, Zhang et al, 2002), pyrochlore and zirconolite (Lumpkin et al., 1986b; Lumpkin and Ewing, 1988; Farges et al., 1993; Farges, 1997), apatite (Ouchani et al 1997), and thorite-group (Lumpkin and Chakoumakos, 1988; Farges and Calas, 1991).

However, radioactive minerals not only irradiate themselves, but also the surrounding non- radioactive minerals. This produces concentric structures called "pleochroic halos" or "radiohaloes", very familiar to petrologists, who use them to identify radioactive minerals in metamorphic or plutonic rocks. In contrast to the numerous studies dealing with radiation effects in radioactive minerals themselves, the effect of radiation damages host minerals are rare. The first time that such halo around mineral inclusions was interpreted as being du to the radioactivity of these inclusions was 100 years ago (Mügge, 1907; Joly, 1907). After that, studies on radiohalos were published between the seventies and the nineties (e.g. Gentry, 1973; 1974; Owen, 1988; Odom and Rink, 1989; Meunier et al., 1990). Recently, only two papers deal with radiohalos: in biotite (Nasdala et al., 2001) and in chlorite and cordierite (Nasdala et al., 2006). These latter studies demonstrated that radiohaloes are created by $\alpha$ particles and correspond only to modification of optical characteristics of the host mineral, the various energies of the $\alpha$-particles explaining the difference in size of the haloes. Furthermore, those authors found intensive damage (i.e. amorphous domains visible via TEM) only in cordierite up to a few tens of nanometers away from radioactive inclusions. They interpreted these damage zones to recoil nuclei. Such amorphous zones at the vicinity of a radioactive mineral has already been observed by using Focused lon Beam-Transmission Electron Microcopy (FIBTEM) across monazite-quartz boundaries by Seydoux-Guillaume et al. (2003); in this case, the zone was $\sim 150 \mathrm{~nm}$ wide.

However, other consequences of radiation damage have not been evaluated. In rocks, poorly crystallized areas, such as the metamict grains but also the damaged zone around them, are actually zones, which can be used by geological fluids to initiate alteration. Another important effect is swelling produced by radiation damage, which can induce cracks around the enclosing minerals, forming pathways for fluids to penetrate into the rock. 
The aim of this study is to investigate, by various electron microscopy techniques, the effect of irradiation in a radioactive mineral (uranothorianite) and in the surrounding minerals (calcite and diopside). The geological consequences of radioactive damage for the non-radioactive host minerals and for the whole-rock itself will be discussed.

\section{Sample Description}

The studied sample (SB540) is a diopside-bearing marble within skarns from the Tranomaro area (Andranomitrohy open pit at $46^{\circ} 33.15^{\prime}$ E, $24^{\circ} 19.97^{\prime}$ S) in South-East Madagascar, metamorphosed under granulitic conditions (4-5 kbar, $800-850^{\circ} \mathrm{C}$; Rakotondrazafy et al., 1996) during the Pan-African orogeny (565-580 Ma, Paquette et al., 1994). In this region, at the western border of the Anosyan Belt, uranothorianite mineralization is common (Moine et al., 1985; Boulvais et al., 1998; Ramambazafy 1998; Ramambazafy et al., 1998; Boulvais et al., 2000). They occur in skarns formed by metasomatic alteration of calcitic marbles (Moine et al., 1985). Fluid inclusion study shows that fluids are $\mathrm{CO}_{2}$-rich $\left(\mathrm{X}_{\mathrm{CO}_{2}} \geq 0.8\right)$ and in equilibrium with mineral assemblages (Ramambazafy et al., 1998). The hydrothermal/metasomatic mobility of Th can be explained by transport in F-rich fluids as shown by the widespread occurrence of fluor-phlogopite and fluor-pargasite (Moine et al., 1998; Ramambazafy, 1998).

Minerals are essentially aluminous diopside $(\mathrm{Cpx})$ and calcite $\left(\mathrm{Cc}_{1}\right)$ sometimes containing uranothorianite inclusions; but spinel, pargasite, plagioclase, phlogopite and zirconolite may also be present. Optical microscope pictures (Figure 1) show examples of 3 uranothorianite grains included in diopside + calcite. The uranothorianite grains are systematically associated with structures suggesting that radioactivity significantly modified the host nonradioactive minerals. These include: (1) cracks, visible only in diopside, radiating from uranothorianite; (2) a diffuse optical halo at the calcite-uranothorianite interface; and (3), a wide ( 20-30 $\mu \mathrm{m})$ "reaction zone" along the diopsideuranothorianite interface. Only diopside in contact with uranothorianite show these corona; other diopside crystals are pristine indicating these features are due to irradiation coming from $\alpha$ decay of $U$ and Th.

\section{Analytical methods}

\subsection{Scanning Electron Microscope (SEM) and Electron Microprobe (EMP)}

SEM images and EDX mapping were performed using the JEOL 6360 equipped with a Sahara detector from PGT at the LMTG-Toulouse. Quantitative EMP analyses were obtained using the Cameca SX50 at the LMTGToulouse operating at $15 \mathrm{kV}$ and $20 \mathrm{nA}$ (Table 1).

\subsection{Transmission Electron Microscope (TEM) coupled with Focused-Ion-Beam (FIB) Technique}

Since the aim of this study is to investigate the interfaces between grains in thin section, a site-specific preparation method for TEM analysis is needed. This method is called Focused lon Beam (FIB) and allows cutting site-specific TEM foils, 15-20 $\mu \mathrm{m}$ by 10-15 $\mu \mathrm{m}$, and $\sim 100 \mathrm{~nm}$ thick (for technical details, see, Overwijk et al., 1993; Young, 1997; Roberts et al., 2001 and Wirth, 2004). TEM samples were milled by using gallium ions accelerated to $30 \mathrm{keV}$. The TEM foil is cut perpendicular to the surface of the sample (Figure 2), providing information with respect to the depth of the specimen. The site-specific specimens were prepared with the FEI FIB200 instrument at the GeoForschungsZentrum (GFZ)-Potsdam.

TEM studies were carried out with the Philips CM200 TEM, operating at $200 \mathrm{keV}$, equipped with an energydispersive X-ray analyzer (EDX) with an ultra-thin window, and a $\mathrm{LaB}_{6}$ filament as electron source, and the $\mathrm{FEI}$ Tecnai ${ }^{\mathrm{TM}} \mathrm{G}^{2} \mathrm{~F} 20 \mathrm{X}$-Twin, operating at $200 \mathrm{kV}$, equipped with a $\mathrm{FEG}$ electron source, a high angle annular dark field 
(HAADF) detector, and an EDAX energy-dispersive X-ray analyzer system; both instruments are installed at the GFZ-Potsdam. Additional selected area diffraction (SAED) patterns were also performed at the TEMSCANToulouse with a Jeol $2010\left(200 \mathrm{keV}, \mathrm{LaB}_{6}\right)$ microscope.

\section{Results}

\subsection{Microscopic study}

In agreement with previous studies (Rakotondratsima, 1983; Ramambazafy, 1998), EMP analyses showed that uranothorianite is a solid-solution made of about two-thirds thorianite and third uraninite. The lead content is about 3-4 wt.\% PbO. The SEM-EDX-map (Figure 3) shows that uranothorianite contains many Pb-rich inclusions, demonstrated by EMP and TEM to be galena $\mathrm{PbS}$. The chemical ages calculated from $\mathrm{U}, \mathrm{Th}$, and $\mathrm{Pb}$ content range from 544 to $578 \mathrm{Ma}$, for four analyses, in agreement with the accepted ages for those rocks, but one analysis gives $931 \mathrm{Ma}$, due to high $\mathrm{Pb}$ content. We think that this analysis was contaminated by a galena inclusion, giving an apparently high $\mathrm{Pb}$ content, and then an apparently old age. Clinopyroxene is an Al-rich diopside $\left(X_{m g}=0.92,8.3 \mathrm{wt}\right.$ $\left.\% \mathrm{Al}_{2} \mathrm{O}_{3}\right)$.

The "reaction zone" at diopside-uranothorianite interface (Figure $2 \mathrm{C}$ ) consists of a mixture of calcite (secondary calcite, $\mathrm{Cc}_{2}$ ), with an Al-Mg-Fe-silicate fibrous phase ( $\varphi$ ) (Figure $2 \mathrm{C}$, D and E). EMP coupled with TEM results (Table 1) demonstrated that it is a low T phyllosilicate from the smectite group. Secondary calcite is usually located at the inner part of the reaction zone, along uranothorianite, and is always porous, whereas smectite $(\varphi)$ is located in the outer part along diopside. The diopside-reaction zone grain boundary is locally indented (Figure 2A, $C$ and $D$ ), along the main cleavage direction. The primary calcite-uranothorianite interface is sharp, but calcite in contact with UTh is more less porous on a $\sim 20 \mu \mathrm{m}$ layer (Figure $2 \mathrm{~B}$ and $\mathrm{E}$ ), as is secondary calcite in the reaction zone (Figure 2E).

SEM confirms the presence of cracks radiating around the uranothorianite within clinopyroxene (Figure 2A and D). Possible remnants of cracks were observed within Cc1 (arrow figure 2B). Some fractures extend into the reaction zone (Figure $2 \mathrm{~A}$ and $\mathrm{D}$ ).

\subsection{Nanometric study (FIB/TEM)}

TEM-samples were prepared using the FIB milling technique across the uranothorianite-primary calcite (\#750; Figure 2B), uranothorianite-secondary calcite (\#752) and diopside-reaction zone (\#753) interfaces (Figure $2 \mathrm{C}$ ); one foil was also cut across a fracture (\#1092, Figure 2D). From selected area diffraction (SAD) patterns (Figures $4 \mathrm{~B}$ and $\mathrm{C}$ ), we can conclude that both primary calcite and uranothorianite are crystalline. The only indication of structural modification in those phases, is mottled diffraction contrast in bright field and dark field images, observed mostly in uranothorianite. In this mineral, diffraction spots are split (Figure 4C), probably because of $\mathrm{PbS}$ inclusions (Figure 3-PbM $\alpha$ map).

Uranothorianite-primary calcite interface (Figure 4 and 5): in contrast to what was observed with SEM, there is no direct contact between primary calcite and uranothorianite. Four different zones $(A, B, C$ and $D)$ were identified (Figure 5). From calcite to uranothorianite, we found: (1) a large ( 200-300 nm) amorphous zone (A), enriched in $U$ and Th, but without Si (see U-Th-Si maps in Figure 5) and enriched in Ca (see EDX spectrum Figure 5); (2) a chain (B) of very small ( 20 nm) $\mathrm{ThO}_{2}$ crystals free of $U$ (Figures 4 and 5); (3) another amorphous zone (C), which, in contrast to zone A is enriched in $\mathrm{Si}$; and (4) another zone (D) made of small amorphous Si-rich "bubbles". Many fluid inclusions were observed in the calcite, some of them displaying a "negative crystal" shape (arrow Figure 4A). Diopside-reaction zone interface (Figure 6): the FIB cut foil shows preferential dissolution of Cpx along cleavages, giving this particular triangular-shaped boundary (Figure 6A). Within the reaction zone an unoriented clay mineral 
(smectite) was observed, with its typical layer-form (Figure 6B and $\mathrm{C}$ ). Many inclusions are present in this zone (arrows on Figure 6): Pb-rich inclusions as well as and $U_{+}$Th-rich inclusions.

Uranothorianite-secondary calcite interface (Figure 7): the organization is similar, but opposite to the uranothorianite-primary calcite interface. An amorphous zone (A) enriched in $\mathrm{U}$, Th and $\mathrm{Ca}$ and a chain of $\mathrm{ThO}_{2}$ crystals (B) parallel to the interface was observed. However the $\mathrm{ThO}_{2}$ layer is mostly along calcite, and not along uranothorianite, and no Si-rich zone was observed. Secondary calcite contains many fluid inclusions (see arrows in Figure $7 \mathrm{~A}$ and $\mathrm{C}$ ) and $\mathrm{U}+\mathrm{Th}+\mathrm{Pb}$ rich inclusions (large inclusion figure $7 \mathrm{~A}$ ).

Within one crack (Figure 8$)$ : the fracture ( $2 \mu \mathrm{m}$ wide) is filled with a mixture of clay mineral and calcite similar to the reaction zone. It contains also ZrTiCaTh-amorphous phase (Zr), presumably metamict zirconolite, already described in those rocks (Rakotondrazafy et al., 1996). Nano-channels are visible at the interface between diopside and the crack border; the channel is larger ( $70 \mathrm{~nm}$ compared to $\sim 40 \mathrm{~nm}$ ) on the upper side (Figure $8 \mathrm{~A}$ and $\mathrm{B}$ ). Bright field (BF) image of the upper channel (Figure $8 \mathrm{~B}$ ) shows that it is filled with nano-bubbles, i.e. fluid inclusions.

\subsection{Summary of petrographic features}

The aureole along the diopside-uranothorianite interface is not a pleochroic halo such as described by Nasdala et al. (2001) in biotite or Nasdala et al. (2006) in cordierite. It is a totally transformed zone, filled with material that we could expect to form during low-temperature retrogression of diopside. The transformed zone is rather constant in thickness: 20 to $38 \mu \mathrm{m}$, with an average at $27 \mu \mathrm{m}$. The transition to pristine diopside is very sharp, but sometime indented. The transformations in primary calcite are less visible but there is actually a porous calcite layer, again 20 to $30 \mu \mathrm{m}$ thick, although it is there more difficult to estimate. At the nano-scale, the uranothorianite-calcite interfaces are quite complex, with several layers, of various chemical compositions and structural states.

Those observations suggest that primary calcite and diopside located close to uranothorianite has been crystallized at low temperature, as a secondary porous calcite for calcite, and as a mixture of secondary calcite and clay mineral for diopside. The presence of hydrous minerals (smectite) and carbonate (calcite) in reaction zone and in cracks, the presence of $\mathrm{Pb}$-rich inclusions in secondary calcite, the abundance of fluid inclusions in the porous layer in primary calcite, the dissociation of $\mathrm{U}$ and $\mathrm{Th}$ in the calcite-uranothorianite layer, and the $\mathrm{ThO}_{2}$ chains along interfaces, are all strong indications that low-temperature crystallization was promoted by a fluid phase.

Surprisingly, truly metamict material is very rare, limited to a narrow (200-300 nm) amorphous layer, along the calcite uranothorianite interface. However all structures describe above are strictly limited to the interface between uranothorianite and other minerals, so must be more or less related to the effect of irradiation. In order to evaluate how irradiation by $U$ and Th could affect the minerals studied above, we carried out a detailed study of irradiation damages using the SRIM/TRIM software.

\section{Modeling with SRIM/TRIM}

Damage was modeled by using the SRIM/TRIM software package (Ziegler, 2006) which allows simulating the effect a particle in a target, knowing what kind of particle it is, and its energy, and the density and chemical compositions of the target. It is based on full-quantum calculations of individual interactions of incident particles with the atoms of the target. For our purpose the interesting outputs are the particle path (in three dimensions), and the vacancies created in the target. SRIM/TRIM always assumes that the target is amorphous and isotropic. 


\subsection{Irradiation by $U$ and Th chains}

Irradiation by $U$ and Th is done by all the radioelements of the ${ }^{235} \mathrm{U},{ }^{238} \mathrm{U}$, and ${ }^{232} \mathrm{Th}$ decay chains which combine $\alpha$ and $\beta$ decays to reach the final stable nuclei: ${ }^{207} \mathrm{~Pb},{ }^{206} \mathrm{~Pb}$ and ${ }^{208} \mathrm{~Pb}$ respectively. We will neglect the $\beta$ decay which produces no major damage, and we will neglect also $\alpha$ decays of minor branched radioactivity. During $\alpha$ decay, two particles are created: the $\alpha$ particle itself, which is a ${ }^{4} \mathrm{He}$ nucleus, and the recoil nucleus, which is actually the nucleus of the daughter element, belonging to elements from $U$ to Tl. The total energy involved during an $\alpha$ decay is few $\mathrm{MeV}$, distributed unevenly between the two particles (about $100 \mathrm{keV}$ for the recoil, and the rest for the $\alpha$ ). Then each $\alpha$ decay produces a slow, heavy nucleus (recoil), and a light, fast particle $(\alpha)$. Another source of damage in radioactive minerals is the spontaneous fission of ${ }^{238} \mathrm{U}$. It is a rare event $\left(0.00005 \%\right.$ of the ${ }^{238} \mathrm{U}$ decay) but the energy involved is about $200 \mathrm{MeV}$, and it produces two fissions nuclei with atomic number around 100 and 140 respectively. The energies of the particles of the three decay chains are summarized in table 2. For $\alpha$ particles, it ranges from 4 to $8.8 \mathrm{Mev}$ and for recoil for from 70 to $170 \mathrm{keV}$.

Using SRIM we calculated the effect of $\alpha$ and recoil particles of the three decay chains, in diopside, calcite and urano-thorianite, as well as the effect of two typical fission products ${ }^{90} \mathrm{Y}$ and ${ }^{140} \mathrm{Ce}$. Usually 1000 particles are calculated to obtain good statistics. Two key outputs are presented in table 2: the average distance reached by the particle, and the number of vacancies created. To illustrate the effect of $\alpha$ and recoil particles in minerals, the vacancy distributions for the ${ }^{214} \mathrm{Po}={ }^{210} \mathrm{~Pb}$ decay in diopside $(\alpha: 7.69 \mathrm{MeV}$; recoil:146 keV), are presented in Figure 9. For other decays or other minerals, the amount of vacancies and the distances are different, but the shapes are similar. The effects of $\alpha$ particles and recoil nuclei are fundamentally different. The $\alpha$ particles are penetratives (12$38 \mu \mathrm{m}$ in diopside, 14 to $45 \mu \mathrm{m}$ in calcite) and produce 220 to 270 vacancies in diopside and 170-200 vacancies in calcite. The recoil nuclei are 1000 times less penetrative (27-45 nm in diopside, $32-55 \mathrm{~nm}$ in calcite) but 10 times more destructive (1200-2500 vacancies in diopside, 940-2030 vacancies in calcite). The fast $\alpha$ particle produces vacancies only at the end of its displacement, when it has been slowed down enough by ionization to interact with target nuclei. The slow recoil nucleus creates vacancies all along its trajectory. In three dimensions, the trajectory of a series of $\alpha$ particles has the shape of a cone, while it is pear-shaped for the recoils. The maximum distance reached by a $\alpha$ particle is very close to the average distance, whereas it is about twice as long for recoil nuclei. Fundamentally the length of the trajectory increases with increasing energy, and decreases with increasing density of the target. In uranothorianite the length of the trajectories are about 15 to $44 \mu \mathrm{m}$ for $\alpha$ particles, so only the outer part of the uranothorianite irradiates the surrounding minerals.

\subsection{Geometry}

SRIM/TRIM simulates only the effect of a particle thrown into a target along a single direction. In the present study we are studying the effect of a layer of radioactive material (the outer part of the uranothorianite grain) into a non-radioactive material (diopside and calcite). The vacancies distribution calculated by SRIM/TRIM must then be corrected. First, because radioactive decay emits particles in random directions and not along a single path, and second, because the emitting volume is a layer and not a point. The main output of SRIM/TRIM is the linear density of vacancies created by a particle, expressed in vacancy/ion/Å, hereafter named $V A C(r)_{\text {linear }}$ with $r$ being the distance (radius). A serie of $N$ particles, along a small distance $d r$ situated at a distance $r$ of the emitting volume creates a number of vacancies $N \times V A C(r)_{\text {linear }} \times d r$. In three dimensions, because of the random direction of the emission, the same amount of vacancies is diluted in a fraction of sphere $4 r^{2} \times d r$. Therefore the vacancy density per ion around an emitting center is: 


$$
\operatorname{VAC}(r)_{\text {sphere }}=\frac{V A C(r)_{\text {linear }}}{4 r^{2}}
$$

This expression is fundamentally the same as in Nasdala et al., (2001), who give the differential form.

As shown in the first part of this paper the thickness of the damaged area $(20-30 \mu \mathrm{m})$ is small compared to the length of the uranothorianite-diopside/calcite interface (few hundreds of $\mu \mathrm{m}$ ). Therefore we will consider the irradiation geometry to be a plane separating a half-space-radioactive from a half-space non-radioactive. Each volume of the irradiated medium situated at a distance $L$ from the interface will receive $\operatorname{VAC}(r)_{\text {sphere }}$ damages from all the particles emitted from the radioactive medium and situated at a distance $r$. The volume of radioactive medium situated at a distance $r$ is:

$$
\operatorname{Vrad}=\times r^{2} \times d r
$$

with $\Omega$ the solid angle of the cone defined by $r$ and $L$, which is given by

$$
=2 \quad 1 \frac{L}{r} \div
$$

Combining equations (1), (2), and (3) and summing over the whole radioactive volume, we obtain the density of vacancies created at a distance $L$ of the radioactive half-space:

$$
V A C(r)_{\text {plane }}={ }_{L} \frac{1}{2} \times V A C(r)_{\text {linear }} \times 1 \frac{L}{r} \div \times d r
$$

Since we do not have an analytical expression for $V A C(r)_{\text {linear }}$, this can only by estimated numerically from the output of SRIM/TRIM. The calculation of the exact expression would require calculating each $V A C(r)_{\text {linear }}$ function for all $L$ and all particles. In order to maintain the calculation time reasonable we decided, for each particle and each target, to use only the $\operatorname{VAC}(r)_{\text {linear }}$ function calculated for the target mineral. The consequences of this approximation will be discussed later.

\subsection{The time scale}

The petrological study showed that the altered aureole was formed by recrystallization of the target minerals, calcite or diopside. To estimate the amount of damage that the target had experienced when recrystallization occurred, we should know the time at which damage started, assumed to be the age of the rock formation (550 Ma), and the time at which alteration and recrystallization occurred, which is unknown. This initial damage at recrystallization is not zero because some lead, presumably radiogenic has been found in the altered aureole, but it can be from few millions to few hundredths of millions years. This is a major uncertainty, which affect the amount of damage and the relative proportion of damages due to the ${ }^{235} \mathrm{U},{ }^{238} \mathrm{U}$ and ${ }^{232} \mathrm{Th}$ chains. However neither the size of the damaged area, which depends only on the nature of the target and the particles energy, nor the shape of the vacancy distribution, which depends mainly on the shape of individual particle damaging and of the geometrical corrections, are affected. All the calculations have been carried out assuming $550 \mathrm{Ma}$ as the irradiation time. As a result of this major uncertainty, we made no attempt to estimate dpa (displacements per atom) from the number of vacancies.

\subsection{Results}

Uranothorianite has been auto-irradiated since its formation. It is possible to calculate the number of vacancies directly from the average damage in Table 2, integrated over $550 \mathrm{Ma}$, and converted it in dpa 
(displacement per atom). The calculated average of 240 dpa over $550 \mathrm{Ma}$, when compared to the dose necessary to completely amorphized thorite $\left(\mathrm{ThSiO}_{4}\right), \sim 0.20 \mathrm{dpa}$ at room temperature (Meldrum et al., 1999), suggests that the Uranothorianite should be completely amorphous. However, because electron diffraction patterns (SAD-Figure 4) demonstrate that it is crystalline, Uranothorianite must self-anneal by some processes. As a comparison, amorphization of $\mathrm{UO}_{2}$ seems impossible, because of the highly rapid recombination of the bonding; for an irradiation dose equivalent to $25 \mathrm{dpa}$ at $\sim 170^{\circ} \mathrm{C}, \mathrm{UO}_{2}$ is still crystalline (Matzke and Turos, 1992; Matzke and Wang, 1996)

Results for diopside and calcite are presented in figure 10 and 11 . Spontaneous fission of ${ }^{238} \mathrm{U}$ is such rare event that it can be neglected. The shapes of the curves, representing the damage due to alpha particles as a function of distance from uranothorianite are similar. Most damage ise accumulated at short distances (about 15 $\mu \mathrm{m}$ in diopside and $17 \mu \mathrm{m}$ in calcite). The more distant part corresponds to the area damaged only by the more energetic particles emitted close to the uranothorianite surface. The total damaged area is then about $35 \mu \mathrm{m}$ wide in calcite and $30 \mu \mathrm{m}$ in diopside. Recoils nuclei create 1000 times more damage than $\alpha$ particles, with a very steep decrease for a damaged zone of $60 \mathrm{~nm}$ in calcite and $50 \mathrm{~nm}$ in diopside.

The thickness of the damaged area calculated for $\alpha$ in diopside is similar to the width of the recrystallized area observed in thin section. The thickness of the porous calcite layer around along the primary calcite-thorianite interface is more difficult to estimate but is also similar to the size of the area damaged by $\alpha$ as calculated above. However the characteristic distances calculated for the damage of recoil nuclei (50 to $60 \mathrm{~nm}$ ) are far away from the size of the totally amorphous layer seen at the calcite-uranothorianite interface (150-250 nm).

\subsection{Effect of wandering recoils}

Modeling the effect of recoil nuclei by a succession of individual ions projected from uranothorianite into the target is, actually, a poor representation of the real process occurring during the radioactive decay of a chain. In decay chains the recoil nucleus is the next radioactive element. During radioactive decay, the recoil moves of few tens of $\mathrm{nm}$, in a random direction. Therefore, there is a possibility, for decay occurring close to the urano-thorianite surface, that after decay the recoil is indeed located out of the uranothorianite. Then next decay will occur inside the diopside (or calcite), and the new recoil will move again, in a random direction. For damages created by $\alpha$ this effect can be neglected, because the path of $\alpha$ is much longer than the possible displacement of the recoil, but for the recoil itself, the damaged area can be significantly enlarged by "the wandering recoil effect": a series of recoils that would move always in the same direction, although very unlikely, can ends few hundredths of $\mathrm{nm}$ inside diopside (or calcite). In order to quantitatively estimate this effect we simulated this effect by the following procedure: (1) for each decay, a random direction is chosen; (2) the average damage is distributed along the path, as calculated by SRIM/TRIM; (3) the recoil (daughter) nucleus is displaced in that direction, at the average distance shown in table 2; (4) the next decay in the chain is processed from this position, as described in (1)-(2)(3). For each chain and for both diopside and calcite we simulated 1000 decay chains. At the end of the calculation, the radial distribution of the damages is calculated. Strictly this procedure only simulates a decay chain initiated exactly at the interface. Again, because we do not know the time scale, but only the shape of the curves, only the characteristics distances have real meanings in this simulation. The results are presented in figure 12. The main result is that the thickness of the area damaged by the recoils is approximately multiplied by 3 because of the "wandering recoil effect". With this correction, the size of the area damaged by recoil nuclei in calcite is in rather good agreement with the thickness of the totally amorphous layer at the calcite-uranothorianite interface (Figures 4 and 7). 


\section{Interpretation and Discussion}

\subsection{A reasonable history of radiohaloes in Tranomaro skarns}

From petrographical study and damage modeling, the evolution of the rock can be reconstructed as follows. The initial rock is a high-temperature skarn, mainly made of aluminous diopside and primary calcite, with some large uranothorianite grains. As soon as the latter is formed, radioactive decays starts, with three consequences:(1) radiogenic $\mathrm{Pb}$ accumulates in uranothorianite; (2) radiation damage accumulates in uranothorianite and in the contiguous minerals; and (3) the uranothorianite grains swells because of radiation damage. For uranothorianite similar to the minerals studied here, Evron et al. (1994) estimated a macroscopic volume expansion of $\sim 1.5 \%$. With increasing time, swelling creates radial cracks in diopside and calcite, as radiation damage accumulates and weakens calcite and diopside around uranothorianite. A heavily damaged (amorphous) thin layer is created along the interface by the recoils, and a partially or totally damaged layer, 20-40 $\mu \mathrm{m}$ is created by $\alpha$. Since no Helium bubbles was observed within uranothorianite by TEM, it is supposed that radiogenic Helium diffused out of the crystal through the cracks. After some time, a low-temperature fluid infiltrates through the rock, using the cracks and the weak interfaces as preferential pathways. The damaged part of diopside is retrogressed as a mixture of clay and secondary calcite. The damaged part of primary calcite recrystallized as a secondary porous calcite layer. At this stage, cracks in calcite are healed, whereas, cracks in diopside are partially filled by various secondary material (Figure 8; calcite, zirconolite, clay mineral). Uranothorianite is also affected by fluids, as shown by the presence of $\mathrm{Pb}, \mathrm{U}$, and Th in the reaction zones (Figure 6 ) and in the amorphous layers $\mathrm{A}$ and $\mathrm{C}$ (Figures 4 and 5), and the presence of $\mathrm{ThO}_{2}$ chains (Figures 4, 5 and 7). However the fact that the chemical ages are in good agreement with the age of the rock indicates that this mineral is not deeply penetrated by fluids. During fluid infiltration, some elements are partially redistributed, including elements which are not obviously present in the thin section such as Zr. After this hydrothermal episode, the newly formed phases are again affected by radioactive damage.

The exact significance of the features observed along the uranothorianite and calcite is at this stage not totally explained. However the $\mathrm{B}$ zone, a chain of $\mathrm{ThO}_{2}$ grains, suggest an in-situ reprecipitation of $\mathrm{ThO}_{2}$ during partial dissolution of uranothorianite, as it is commonly observed in experiments with $\mathrm{ThO}_{2}$ (Seydoux-Guillaume et al., 2002; Heisbourg et al., 2003; Heisbourg et al., 2004).

\subsection{Some properties of uraninite, calcite, and diopside relative to radiation damages}

The observations made on this sample support several hypotheses on the behavior of calcite, diopside and uranothorianite under irradiation. Uranothorianite is remarkably resistant to irradiation damage. This is not unexpected, since uraninite, which is isostructural with Uranothorianite remains crystalline (Janeczek et al 1996, Evron et al 1994). By contrast, a thorium silicate $\left(\mathrm{ThSiO}_{4}\right)$ that accumulated approximately the same dose as the uranothorianite studied here $\left(\sim 5 \times 10^{\mathrm{E} 20} \alpha / \mathrm{g}\right)$ is completely amorphous (Seydoux-Guillaume et al., 2007). This observation is consistent with higher resistance to amorphization by radiation damage (or greater ability to selfanneal) in minerals for which the long-range ionic forces dominates over the short-range covalent forces (Trachenko, 2004), as in the case for Uranothorianite when compared to thorite.

Contrary to our observations of uranothorianite, diopside seems to be highly sensible to radiation damage. The average size of the retrogressed zone is $27 \mu \mathrm{m}$. At this distance the damage is only $2 \%$ of the damage created by the $\alpha$ at the contact with uranothorianite. For $550 \mathrm{Ma}$ of irradiation, this would correspond to $0.0014 \mathrm{dpa}$, so it means that the resistance of diopside relative to low-temperature fluids is modified even if about 1/1000 atoms are displaced. We should recall that $550 \mathrm{Ma}$ is the maximum for the irradiation time since it assumes that retrogression occurred at the present time. 
The limit between pristine diopside and the retrogressed area is very sharp; there is no intermediate zone in which diopside would be partly retrogressed. This suggests that there is a threshold in the sensitivity to damaged diopside to low temperature fluid. Below a certain value of damage the diopside behaves as an undamaged diopside, and is not affected by alteration. We should recall that diopside is a common mineral in heavy minerals concentrates in river, so it is not normally destroyed by low-T fluids.

In calcite the porous layer, which can be assumed to be the equivalent of the retrogressed zone in diopside, is 10 to $15 \mu \mathrm{m}$ wide, as estimated from figure 2 . At this distance damage is 45 to $25 \%$ of the maximum (550 Ma) $\alpha$ damage, for 0.013 to $0.0055 \mathrm{dpa}$. Calcite seems then more resistant to irradiation damage than diopside, probably due to the type of interatomic forces in that structure (Trachenko, 2004). It is important to remember, that diopside crystals that are not in contact with uranothorianite in the rest of the rock are pristine. This demonstrates that irradiation is responsible for the destabilization of diopside by fluids. However, calcite directly in contact with uranothorianite (see presence of $\mathrm{Ca}$ within amorphous zone A (Figure 4A and 5) is amorphous, showing the strong effect of "continuous irradiation by wandering recoil". It should be also noted that calcite is always crystalline, even at the contact with uranothorianite where the damage rate can be up to $0.055 \mathrm{dpa}$.

Outside the modified area around uranothorianite, the rock is very fresh; the only indication of the low-T fluid infiltration is secondary material along the diopside-uranothorianite interfaces and, at nanoscale, in swelling structures, i.e. cracks (Figure 8). This definitely shows that uranothorianite grains create weak zones in the rock, by destroying the surrounding minerals, and by creating swelling cracks.

The thickness of the retrogressed area at the diopside-uranothorianite interface is approximately constant all around the thin section. It means that the effect of irradiation damage in diopside does not depend on the orientation of the diopside crystals although it is an anisotropic chain-silicate. The only visible indication of the anisotropy of diopside is the local presence of indentation at the pristine-retrogressed limit, due to limited fluid infiltration along cleavage surfaces.

\subsection{Reliability of the conclusions}

The above conclusions are based on a detailed study of structures surrounding a single uranothorianite grain. The representativity of the studied zone can then be legitimely questioned. Many features observed around this particular grain are visible in the whole thin section, such as the radiating cracks, the presence of retrogressed zone along the diopside-uranothorianite interface, and the presence of a porous layer along the calciteuranothorianite. Those features are also present in all studied samples of the same rock. Observations at the nanoscale by coupling FIB/TEM analyses, like the presence of a wide amorphous zone along the calciteuranothorianite boundary, or the presence of chains of $\mathrm{ThO}_{2}$ crystals, which are time-consuming, cannot easily be multiplied all around a thin section, but are regular in shape and size, and are in agreement with damage model. Therefore we are quite confident that these are general features in this sample. Moreover, similar observations have been reported in other studies (Nasdala et al., 2006; Seydoux-Guillaume et al., 2003; 2007; SeydouxGuillaume, unpublished), suggesting that it is common in rocks containing radioactive minerals. Some observations are clearly accidental, and may not be representative, such as the presence of zirconolite grains in the fractures.

\subsection{Reliability of the model.}

In this study the SRIM/TRIM model provided several important constraints. This software has the advantage of being the most sophisticated program available for non-specialist; on the other hand it has some limitations; for example it considers all materials as isotropic, and neglects the effect of crystalline structures. However, the fact that the size of damaged area in diopside is constant whatever its orientation provides an a posteriori justification of 
this assumption. Diopside is a chain-based, highly anisotropic structure, and if radiation damage is sensitive to crystal anisotropy, it should be visible in this mineral.

\section{Conclusions}

Radiohalos are complex structures, which deserve detailed study. Since radiation damage has a visible effect at the thin section scale, but also affects the structure of crystals at the atomic scale, studies must be conducted with a variety of techniques, including FIB/TEM for the nanoscale. Radiohalos are unique sources of information for understanding the behaviour of minerals submitted to irradiation damages, even for non-radioactive minerals. This approach one, to study the effects of long-term irradiation and is thus very complementary to other methods that involve doping experiments with short lived isotopes, which are far more expensive.

In the present study we have demonstrated the high resistance of uranothorianite to self-irradiation damage, in agreement with previous results (Evron et al., 1994), and, by contrast, the high sensitivity of diopside to radiation damage from neighbouring uranothorianite. TRIM/SRIM simulations have been shown to be able to correctly simulate radiation damage, even in complex minerals such as diopside.

Finally, we would like to emphasize that radiohalos are actually a point of chemical and mechanical weakness in a rock and probably a starting point for alteration.

\section{Acknowledgements}

FIB/TEM analyses have been done thanks to the financial support for travels to Potsdam from PROCOPE (2005-2006) N09638ZB. The authors want to thank Ph. De Parseval and T. Aigouy for their technical assistance with the Electron Microprobe and with the SEM, and L. Datas and L. Weingarten for their technical assistance with the TEM at the TEMSCAN service from UPS. Constructive comments from R.C. Ewing and an anonymous reviewer were appreciated; we also want to thank J. Hanchar for his excellent editorial work. Thanks to M. Jessel for correcting the English language. 


\section{References}

Balan, E., Allard, T., Fritsch, E., Sélo, M., Falguères, C., Chabaux, F., Pierret, M.P., Calas, G., 2005. Formation and evolution of lateritic profiles in the middle Amazon basin: Insights from radiation-induced defects in kaolinite. Geochimica et Cosmochimica Acta 69, 2193-2204.

Begg, B., Hess, N.J., Weber, W.J., Conradson, S.D., Scheiger, M.J., Ewing, R.C., 2000. XAS and XRD study of annealed ${ }^{238} \mathrm{Pu}$ and ${ }^{239} \mathrm{Pu}$ substituted zircons $\left(\mathrm{Zr}_{0.92} \mathrm{Pu}_{0.08} \mathrm{SiO}_{4}\right)$. Journal of Nuclear Materials 278, 121-224.

Boulvais, P., Fourcade, S., Gruau, G., Moine, B., Cuney, M., 1998. Persistance of premetamorphic C and O isotopic signatures in marbles subject to Pan-African granulite facies metamorphism and U-Th mineralization (Tranomaro, South East Madagascar). Chemical Geology 150, 247-262.

Boulvais, P., Fourcade, S., Moine, B., Gruau, G., Cuney, M., 2000. Rare-earth elements distribution in granulitefacies marbles : a witness of fluid-rock interaction. Lithos 53, 117-126.

Burakov, B.E., Hanchar, J.M., Garbusov, V.M., Zirlin, V.A., 2002. Synthesis and investigation of Pu doped single crystal zircon $\mathrm{ZrPuSiO}_{4}$. Radiochimica acta 90, 95-97.

Crocombette, J.P., Ghaleb, D., 2001. Molecular dynamics modeling of irradiation damage in pure and uranium doped zircon. Journal of Nuclear Materials 295, 167-178.

Davis, D.W., Krogh, T.E., 2000. Preferential dissolution of ${ }^{234} \mathrm{U}$ and radiogenic $\mathrm{Pb}$ from $\alpha$-recoil-damaged lattice sites in zircon: implications for thermal histories and $\mathrm{Pb}$ isotopic fractionation in the near surface environment. Chemical Geology 172, 41-58.

Evron, R., Kimmel, G., Eyal, Y., 1994. Thermal recovery of self-radiation damage in uraninite and thorianite. Journal of Nuclear Materials 217, 54-66.

Ewing, R.C., 1975. The crystal chemistry of complex niobium and tantalum oxides IV. The metamict state: discussion. American Mineralogist 60, 728-733.

Ewing, R.C., Chakoumakos, B.C., Lumpkin, G.R., Murakami, T., Greegor, R.B., Lytle, F.W., 1988. Metamict minerals: natural analogues for radiation damage effects in ceramic nuclear waste forms. Nuclear Instruments and Methods in Physics Research B32, 487-497.

Ewing, R.C., 1994. The metamict state: 1993-the centennial. Nuclear Instruments and Methods in Physics Research B91, 22-29.

Ewing, R.C., Weber, W.J., Clinard, F.W.Jr., 1995. Radiation effects in nuclear waste forms. Progress in Nuclear Energy 29, 63-127.

Ewing, R.C., Meldrum, A., Wang, L.M., Wang, S.X., 2000. Radiation-induced amorphisation. In: Redfern, S.A.T., Carpenter, M.A., Ribbe, P.H. (eds.), Transformation Processes in Minerals. Reviews in Mineralogy and Geochemistry, Mineralogical Society of America 39, 319-361.

Ewing, R.C., Wang, L.M., 2002. Phosphates as Nuclear Waste Forms. In: Kohn, M.J., Rakovan, J., Hughes, J.M., Ribbe, P.H. (eds.), Phosphates: Geochemical, Geobiological and Materials importance. Reviews in Mineralogy and Geochemistry, Mineralogical Society of America 48, 673-699.

Ewing, R.C., Meldrum, A., Wang, L.M., Weber W.J., Corrales, L.R., 2003. Radiation damage in zircon. In: Hanchar, J.M., Hoskin, P.W.O. (eds), Zircon. Reviews in Mineralogy and Geochemistry, Mineralogical Society of America 53, 387-425.

Farges, F., Calas, G., 1991. Structural analysis of irradiation damage in zircon and thorite. An X-ray absorption spectroscopic study. American Mineralogist 76, 60-73.

Farnan, I., Balan, E., Pickard, C.J., Mauri, F., 2003. The effect of radiation damage on local structure in the crystalline fraction of $\mathrm{ZrSiO}_{4}$ : Investigating the Si-29 NMR response to pressure in zircon and reidite. American Mineralogist 88, 1663-1667. 
Gentry, R.V., 1973. Radioactive halos. Annual review in Nuclear Science 23, 347-362.

Gentry, R.V., 1974. Radiohalos in a radiochronological and cosmological perspective. Science 184, 62-66.

Harfouche, M., Farges, F., Crocombette, J.-P., Flank, A.-M., 2005. XAFS and molecular dynamics study of the structural environment around actinides and network formers in natural minerals analogues of ceramics for nuclear waste storage. Physica Scripta T115, 928-930.

Hawthorne, F.C., Groat, L.A., Raudsepp, M., Ball, N.A., Kimata, M., Spike, F.D., Gaba, R., Halden, N.M., Lumpkin, G.R. , Ewing, R.C., Greegor, R.B., Lytle, F.W., Ercit, T.S., Rossman, G.R., Wicks, F.J., Ramik, R.A., Sherriff, B.L., Fleet, M.E., McCammon, C., 1991. Alpha-decay damage in titanite: American Mineralogist, 76, 370396.

Headley, T.J., Ewing, R.C., Haaker, R.F., 1981. Amorphous structure of metamict minerals observed by TEM. Nature 293, 449-450.

Heisbourg, G., Hubert, S., Dacheux, N., Ritt, J., 2003. The kinetics of dissolution of $T h_{1-x} U_{x} O_{2}$ solid solutions in nitric media. Journal of Nuclear Materials 321, 141-151.

Heisbourg, G., Hubert, S., Dacheux, N., Purans, J., 2004. Kinetic and thermodynamic studies of the dissolution of thoria-urania solid solutions. Journal of Nuclear Materials 335, 5-13.

Janeczek, J., Eby, R.K., 1993. Annealing of radiation damage in allanite and gadolinite. Physics and Chemistry of Minerals 19, 343-356.

Janeczek, J., Ewing, R.C., Oversby, V.M., Werme, L.O., 1996. Uraninite and $\mathrm{UO}_{2}$ in spent nuclear fuel: a comparison. Journal of Nuclear Materials 238, 121-130.

Joly, J., 1907. Pleochroic Halos. Philosophical Magazine 13, 381-383.

Lumpkin, G.R., Chakoumakos, B.C., Ewing, R.C., 1986a. Mineralogy and radiation effects of microlite from the Harding Pegmatite, Taos County, New Mexico. American Mineralogist, 71, 569-588.

Lumpkin, G.R.,Ewing, R.C., Chakoumakos, B.C., Greegor, R.B., Lytle F.W., Forltyn, E.M., Clinard, F.W. Jr., Boatner, L.A., Abraham, M.M. 1986b. Alpha-recoil damage in zirconolite $\left(\mathrm{CaZrTi}_{2} \mathrm{O}_{7}\right)$. Journal of Material Research 1, 564-576.

Lumpkin, G.R., Chakoumakos, B.C., 1988. Chemistry and radiation effects of thorite-group minerals from the Harding pegmatite, Taos County, New Mexico. American Mineralogist 73, 1405-1419.

Lumpkin, G.R., Ewing, R.C., 1988. Alpha decay damage in minerals of the pyrochlore group. Physics and Chemistry of Minerals 16, 2-20.

Lumpkin, G.R., Eby, R.K., Ewing, R.C. 1991. Alpha-recoil damage in titanite $\left(\mathrm{CaTiSiO}_{5}\right)$ : direct observation and annealing study using high resolution transmission electron microscopy. Journal of Material Research 6 , 560-564.

Linberg, M.L., Ingram, B. 1964. Rare-earth silicatian apatite from the Adirondack Mountains, New-York. US Geological Survey Professional Paper 501-B, B64-B65.

Matzke, H.j., Turos, A., 1992. Ion implantation studies of $\mathrm{UO}_{2}$ and $U N$. Journal of Nuclear Materials 188, 285-292.

Matzke, Hj, Wang, L.M., 1996. High-resolution transmission electron microscopy of ion irradiated uranium oxide. Journal of Nuclear Materials 231, 155-158.

Meldrum, A., Boatner, L.A., Weber, W.J., Ewing, R.C., 1998. Radiation damage in zircon and monazite. Geochimica et Cosmochimica Acta 62, 2509-2520.

Meldrum, A., Zinckle, S.J., Boatner, L.A., Ewing, R.C., 1999. Heavy-ion irradiation effects in the ABO4 orthosilicates: decomposition, amorphization, and recrystallization. Physical Review B59, 3981-3992.

Meunier, J.D., Sellier, E., Pagel, M., 1990. Radiation damage rims in quartz from uranium bearing sandstones. Journal of Sedimentary Petrology 60, 53-58. 
Moine, B., Rakotondratsima, C., Cuney, M., 1985. Les pyroxénites à urano-thorianite du sud-est de Madagascar, conditions physico-chimiques de la métasomatose. Bulletin de Minéralogie 108, 325-340.

Moine, B., Ramambazafy, A., Rakotondrazafy, M., Ravololomiandrinarivo, B., Cuney, M., de Parseval, P., 1998. The role of fluorine-rich fluids in the formation of the thorianite and sapphire deposits of S.E. Madagascar. In: $8^{\text {th }}$ Goldschmidt Conference, Mineralogical Magazine 62A, 999-1000.

Mügge, O., 1907. Radioaktivität als Ursache der pleochroitischen Höfe. Zentralblatt Mineralogie Geologie 71, 529532.

Nasdala, L., Irmer, G., Wolf, D., 1995. The degree of metamictization in zircons a raman spectroscopic study. European Journal of Mineralogy 7, 471-478.

Nasdala, L., Wenzel, M., Andrut, M., Wirth, R., Blaum, P., 2001. The nature of radiohaloes in biotite : experimental studies and modeling. American Mineralogist 86, 498-512.

Nasdala, L., Wildner, M., Wirth, R., Groshopf, N., Pal, D.C., Möller, A., 2006. Alpha particle haloes in chlorite and cordierite. Mineralogy and Petrology 86, 1-27.

Odom, A.L., Rink, W.L., 1989. Giant radiation-induced colored halos in quartz solution to a riddle. Science 246, 107-109.

Ouchani, S., Dran, J.C., Chaumont, J., 1997. Evidence of ionization annealing upon helium-ion irradiation of predamaged fluorapatite. Nuclear Instruments and Methods, Physical Research B132, 447-451.

Owen, M.R., 1988. Radiation damage halos in quartz. Geology 16, 529-532.

Paquette, J.L., Nédélec, A., Moine, B., Rakotondrazafy, M. 1994. U-Pb, single zircon evaporation and Sm-Nd isotopic study of a granulite domain in SE Madagascar, Journal of Geology 102, 523-538.

Rakotondrazafy, M., 1995. La hibonite $\left(\mathrm{CaAl}_{12} \mathrm{O}_{19}\right)$ du Sud-Est de Madagascar. Caractères et modalités de formation dans les skarns à thorianite du faciès granulite (Unpublished). Thesis, Antananarivo University, Madagascar.

Rakotondrazafy, M., Moine, B., Cuney, M., 1996. Mode of formation of hibonite (CaAl12O19) within the U-Th skarns from the granulites of S-E Madagascar. Contribution to Mineralogy and Petrology 123, 190-201.

Ramambazafy, A., 1998. Granites et fluides en relation avec les skarns à thorianite dans les granulites du S.E. de Madagascar. Thesis, Paul Sabatier Toulouse III University, 302 pp.

Ramambazafy, A., Moine, B., Rakotondrazafy, M., Cuney, M., 1998. Signification des fluides carboniques dans les granulites et les skarns du Sud-Est de Madagascar. Compte Rendu de l'académie des sciences 327, 743748.

Romer, R., 2003. Alpha-recoil in U-Pb geochronology: effective sample size matters. Contribution to Mineralogy and Petrology 145, 481-491.

Seydoux-Guillaume, A.M., Paquette, J.L., Wiedenbeck, M., Montel, J.M., Heinrich, W., 2002. Experimental resetting of the U-Th-Pb systems in monazite. Chemical Geology 191, 165-181.

Seydoux-Guillaume, A.M., Goncalves, P., Wirth, R., Deutsch, A., 2003. TEM study of polyphasic and discordant monazites: site specific specimen preparation using the Focused Ion Beam technique. Geology 31, 973976.

Seydoux-Guillaume A.M., Wirth R., Deutsch A. and Schärer U. (2004). Microstructure of 24 - 1928 Ma concordant monazites: implications for geochronology and nuclear waste deposits. Geochimica et Cosmochimica Acta 68, 2517-2527.

Seydoux-Guillaume, A.M., Wirth, R., Ingrin, J., 2007. Contrasting response of $\mathrm{ThSiO}_{4}$ and monazite to natural irradiation. European Journal of Mineralogy 19, 7-14.

Trachenko, K.O., 2004. Understanding resistance to amorphization by radiation damage. Journal of Physics: Condensed Matter 16, 1491-1515 
Trachenko, K.O., Dove, M.T., Salje, E.K.H., 2001. Atomistics modeling of radiation dammage in zircon Journal of Physics: Condensed Matter 13, 947-952.

Wang, L.M., Ewing, R.C., 1992. Ion beam induced amorphization of complex ceramic materials - minerals: Materials Research Society Bulletin 13, 38-44.

Weber, W.J., Ewing, R.C., Catlow, C.R.A., Diaz de la Rubia T., Hobbs, L.W., Kinishita, C., Matzke, H.J., Motta, A.T., Nastasi, M., Salje, E.H.K., Vance, E.R., Zinkle, S.J., 1998. Radiation effects in crystalline ceramics for the immobilization of high-level nuclear waste and plutonium. Journal of Material Research 13, 1434-1484.

W.J. Weber, W.J., Ewing, R.C., Wang, L.M., 1994. The radiation-induced crystalline-to-amorphous transition in zircon: Journal of Materials Research 9, 688-698.

Wirth, R., 2004. Focused Ion Beam (FIB): A novel technology for advanced application of micro- and nanoanalysis in geosciences and applied mineralogy. European Journal of Mineralogy 16, 863-876.

Zhang, M., Salje, E.K.H., Bismayer, U., Groat, L.A., Malcherek, T., 2002. Metamictization and recrystallization of titanite: an infrared spectroscopic study. American Mineralogist 87, 882-890.

Zhang, M., Salje, E.K.H., 2001. Infrared spectroscopic analysis of zircon: radiation damage and the metamict state. Journal of physics: condensed matter 13, 3057-3071.

Ziegler, J.F., 2006. SRIM: The stopping and range of ions in matter. Instruction manual 


\section{Figure captions}

Figure 1. Optical microscope images showing 3 uranothorianite (UTh) grains included in diopside (Cpx) + calcite (Cc) under crossed polars light. Note the associated structures due to irradiation from $\alpha$ decay of $U$ and Th: (1) cracks, visible only in diopside, radiating from uranothorianite; (2) a diffuse optical halo at calcite-uranothorianite interface; and (3) a wide ( 20-30 $\mu \mathrm{m})$ "reaction zone" along diopside-uranothorianite interface.

Figure 2. Scanning Electron Microscope (SEM) images in Secondary Electron (SE) mode from UTh $+\mathrm{Cc}_{1}+\mathrm{Cpx}$ shown in Figure 1 (left one). A- Note the associated structures due to irradiation from $\alpha$ decay of $U$ and Th: (1) cracks, visible only in diopside, radiating from uranothorianite; (2) a diffuse optical halo at calcite-uranothorianite interface; and (3) a wide $(\sim 20-30 \mu \mathrm{m})$ "reaction zone" along the diopside-uranothorianite interface. Within this reaction zone, 2 other phases were observed: a secondary calcite $\left(\mathrm{Cc}_{2}\right)$ and a clay mineral $(\varphi 7 \mathrm{FIB}$ holes and electron microprobe analyses (see numbers) were also done. B- FIB hole across UTh-Cc boundary (\# 750). Note the porosity within $\mathrm{Cc}_{1}$ and possible remnant of cracks (see arrow). C- Enlargement within the "reaction zone" showing mixture of a secondary calcite $\left(\mathrm{CC}_{2}\right)$ and a low T clay mineral $(\varphi)$. and FIB holes done across UTh- $\varphi$ (\# 752) and $\varphi$-Cpx (\# 753) boundaries. D- Enlargement within the "reaction zone" showing fractures within diopside, with some extended into the reaction zone (arrow), and FIB hole cut across one crack (\# 1092). E- Enlargement within the "reaction zone" showing high porosity within $\mathrm{Cc}_{2}$.

Figure 3. SEM chemical maps of PbM $\alpha$, SiK $\alpha$, ThL $\alpha, A I K \alpha$, CaK $\alpha, M g K \alpha$ and FeK $\alpha$ of the zone observed in the Back Scattered Electron (BSE) image on the left. Acquisition time was $12.4 \mathrm{sec} / \mathrm{image}$ for a total of 140 images and a size of maps of $256 \times 192 \times 16$ bits. Note of the high quantity of PbS inclusions within UTh.

Figure 4. TEM foil \# 750. A- Energy Filtered Transmission Electron Microscope (EFTEM) - Bright Field (BF) image showing presence of an amorphous zone $(A)$ between primary calcite $\left(\mathrm{Cc}_{1}\right)$ and $\mathrm{UTh}$. Zone $(\mathrm{B})$ correspond to $\mathrm{ThO}_{2}$ grains and zone $(C)$ to another amorphous zone (see Figure 5). Many fluid inclusions were observed in the calcite, some of them displaying a "negative crystal" shape (see arrow). B and C- Selected area Diffraction (SAD) patterns in respectively primary calcite and UTh showing that both phases are crystalline. In UTh diffraction spots are split probably because of the presence of PbS inclusions within UTh (arrows).

Figure 5. TEM foil \# 750. EFTEM-BF image (on the top on the left), and $U$, Th, Si-jump ratio maps of the same zone showing from calcite to uranothorianite: (1) a large ( 200-300 nm) amorphous zone (A), enriched in $U$ and Th, but without $\mathrm{Si}$ (see $\mathrm{U}$, Th and Si maps) and enriched in $\mathrm{Ca}$ (see EDX spectrum on the right); (2) a chain (B) of very small ( 20 nm) $\mathrm{ThO}_{2}$ crystals free of $\mathrm{U}$; (3) another amorphous zone (C), which, in contrast to zone $A$ is enriched in $\mathrm{Si}$ (see EDX spectrum on the right and Si-map); and (4) another zone (D) made of small amorphous Si-rich "bubbles".

Figure 6. TEM foil \# 753. Scanning Transmission Electron Microscope Bright Field (STEM-BF) image (A) and EFTEM-BF images (B and C) showing preferential dissolution of diopside ( $\mathrm{Cpx}$ ) along cleavages, giving this particular triangular-shaped boundary, an unoriented clay mineral ( $\varphi$-smectite), with its typical layer-form (B and C), and many $\mathrm{Pb}$-rich as well as $\mathrm{U}_{+}$Th-rich inclusions (arrows in $\mathbf{A}$ and $\mathbf{C}$ ). 
Figure 7. TEM foil \# 752. STEM-BF image (A) and EFTEM-BF images (B and C) showing a similar organization but reversed from the uranothorianite- $\mathrm{Cc}_{1}$ interface: an amorphous zone $(\mathrm{A})$ enriched in $\mathrm{U}$, Th and $\mathrm{Ca}$ and a chain of $\mathrm{ThO}_{2}$ crystals (B) parallel to the interface (see also image $B$ ). Secondary calcite $\left(\mathrm{Cc}_{2}\right)$ contains many fluid inclusions (see arrows in $\mathbf{A}$ and $\mathbf{C}$ ) and $\mathrm{U}_{+} \mathrm{Th}+\mathrm{Pb}$ rich inclusions (large inclusion on the right).

Figure 8. TEM foil \# 1092. STEM-Dark Field (DF) image (A) done with high angle annular dark field (HAADF) detector and TEM-BF images (B and C) showing TEM-foil cut across one fracture within Cpx (see Figure 1D). The fracture ( $2 \mu \mathrm{m}$ wide) is filled with a mixture of clay mineral $(\varphi)$, calcite (Cc), and a ZrTiCaTh-amorphous phase $(\mathrm{Zr})$, presumably metamict zirconolite $(\mathbf{A})$. Nano-channels, filled with nano-bubbles (fluid inclusions) are visible at the interface between $\mathrm{Cpx}$ and the crack border (B); the channel is larger ( 70 nm compared to $\sim 40 \mathrm{~nm}$ ) on the upper side (A and B).

Figure 9. Projection of the vacancy distribution created by a 7.69 MeV $\alpha$ particle (A) and the corresponding recoil (B) nuclei $\left({ }^{210} \mathrm{~Pb}\right.$ at $\left.146 \mathrm{keV}\right)$ in diopside. The fast $\alpha$ particle produces vacancies only at the end of its displacement, when it has been slowed down enough by ionization to interact with target nuclei. The slow recoil nucleus creates vacancies all along its trajectory. Note that vertical and horizontal scales are very different in the two figures.

Figure 10. Spatial distribution of the vacancies created in calcite by $\alpha$ particles $(\mathbf{A})$ and recoil nuclei $(\mathbf{B})$ emitted by uranothorianite. The calculation includes all particles from the three decay chains, integrated for $550 \mathrm{Ma}$. It assumes that urano-thorianite is a semi-infinite emitting medium irradiating a semi-infinite calcite half-space, separated by a plane. Note that vertical and horizontal scales are very different in the two figures.

Figure 11. Spatial distribution of the vacancies created in diopside by $\alpha$ particles $(\mathbf{A})$ and recoil nuclei (B) emitted by uranothorianite. The calculation includes all particles from the three decay chains, integrated for $550 \mathrm{Ma}$. It assumes that urano-thorianite is a semi-infinite emitting medium irradiating $n$ semi-infinite diopside half-space, separated by a plane. Note that vertical and horizontal scales are very different in the two figures.

Figure 12. Spatial distribution of the vacancies created in diopside $(\mathbf{A})$ and calcite $(\mathbf{B})$ by wandering nuclei. The model simulates the random trajectories of recoil nuclei during the successive decays in the three decay chains, and estimates, via TRIM/SRIM simulation the vacancies created along the path. The integration time is $550 \mathrm{Ma}$. Those diagrams should be compared to Figure 10 and 11 (B) 